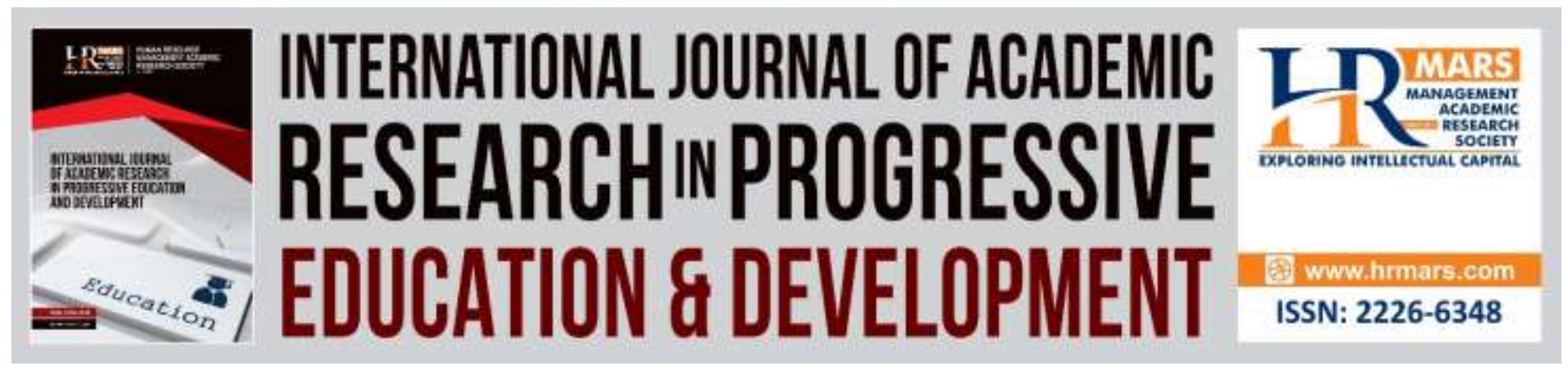

\title{
The Use of I-Think Thinking Map in Mastering Malay Language as a Second Language Among Bidayuh Students in Serian District, Sarawak, Malaysia
}

\section{Zamri Mahamod, Christine Anak Linsah \& Hadi Hassan}

To Link this Article: http://dx.doi.org/10.6007/IJARPED/v8-i4/6667

DOI:10.6007/IJARPED/v8-i4/6667

Received: 17 October 2019, Revised: 23 November 2019, Accepted: 30 November 2019

Published Online: 04 December 2019

In-Text Citation: (Mahamod, Linsah, \& Hassan, 2019)

To Cite this Article: Mahamod, Z., Linsah, C. A., \& Hassan, H. (2019). The Use of I-Think Thinking Map in Mastering Malay Language as a Second Language Among Bidayuh Students in Serian District, Sarawak, Malaysia. International Journal of Academic Research in Progressive Education and Development, 8(4), 581600.

Copyright: (C) 2019 The Author(s)

Published by Human Resource Management Academic Research Society (www.hrmars.com)

This article is published under the Creative Commons Attribution (CC BY 4.0) license. Anyone may reproduce, distribute, translate and create derivative works of this article (for both commercial and non-commercial purposes), subject to full attribution to the original publication and authors. The full terms of this license may be seen at: http://creativecommons.org/licences/by/4.0/legalcode

Vol. 8(4) 2019, Pg. 581 - 600

http://hrmars.com/index.php/pages/detail/IJARPED

JOURNAL HOMEPAGE

Full Terms \& Conditions of access and use can be found at http://hrmars.com/index.php/pages/detail/publication-ethics 


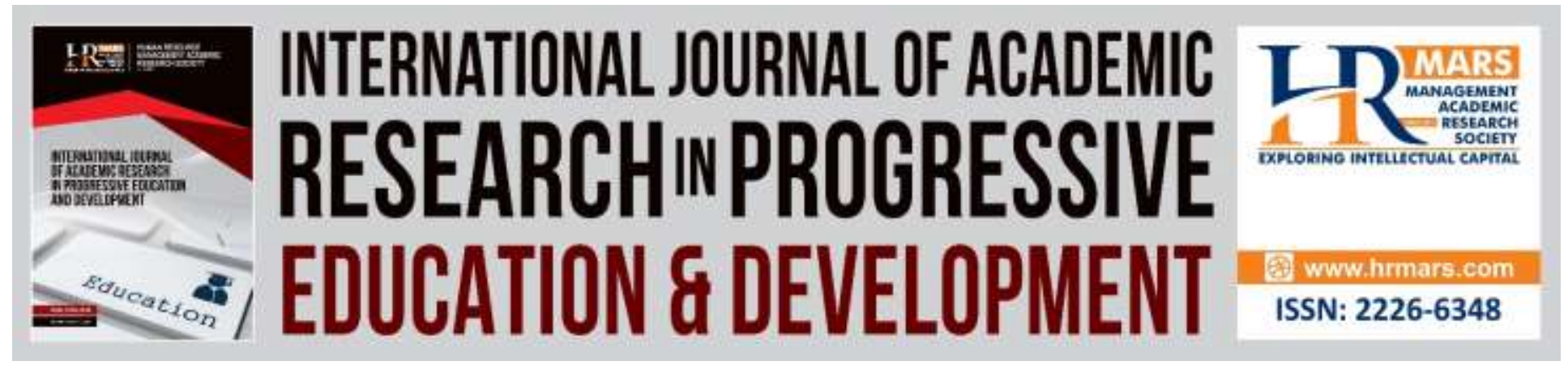

\title{
The Use of I-Think Thinking Map in Mastering Malay Language as a Second Language Among Bidayuh Students in Serian District, Sarawak, Malaysia
}

\author{
Zamri Mahamod, Christine Anak Linsah \& Hadi Hassan \\ Faculty of Education, Universiti Kebangsaan Malaysia, 43600 UKM, Bangi, Selangor Darul Ehsan, \\ Malaysia
}

\begin{abstract}
This study is conducted to identify i-THINK Thinking Map usage as a thinking tool for mastering Malay language as a second language. The survey is conducted quantitatively involving 234 Form Four Bidayuh Bukar Sadung (BBS) students from four secondary schools in Serian District, Sarawak, Malaysia. Questionnaire instrument using five-points Likert is used to collect data on knowledge and acceptance of students on i-THINK Thinking Map as well as the level of mastery of Malay language among students. The data are analyzed using SPSS (Statistical Package for Social Sciences Version 22.0). Descriptive statistics such as frequency, percentage, mean and standard deviation are used to answer the research questions while inferential statistics that are chi square test and Spearman's rho correlation test are used to answer the research hypothesis. The findings show that the level of knowledge of the respondents on the name and process of $i$ THINK Thinking Maps is at a low level but the knowledge on their use in Malay language T\&L is moderate (average mean score $=3.57$ ). The overall mean level of the acceptance of i-THINK Map and the mastery of pupils in Malay language is high in which acceptance (3.82) and mastery (3.75). In addition, the results show that there is no significant relationship between knowledge and acceptance of i-THINK Map usage with Malay Language mastery of among students.
\end{abstract}

Keywords: Knowledge, Acceptance Mastery, Thinking Maps, Bidayuh Ethnic Students

\section{Introduction}

Implementation of i-THINK program by the Ministry of Education Malaysia (MoE) comes with the aim of improving and inculcating thinking skills among school children towards producing innovative students that have High Level Thinking Skills (HOTS). I-THINK thinking map has been founded and developed by Hyerle (1996). In his book entitled Visual Tools for Constructing Knowledge (Association for Supervision and Curriculum Development, 1996), the implementation grassroots of this program focuses on comprehensive research on how teachers become facilitators in producing creative and analytical minds as well as understanding concepts and thinking systematically through visual thinking tools. 
In KBSM Malay Language Learning Syllabus, there are four language skills that must be mastered by students namely listening, speaking, reading and writing skills (MoE, 2000). According to Loganathan (2014), mastery of language skills requires diversity of situations and contexts that include various thinking skills that can be presented in the form of graphical and visual thinking map. Malay language is the second language for non-Malay language speakers. Formal second language learning depends on several factors such as intrinsic, sociopolitical, linguistic, pedagogy and others (Zamri et al. 2013). They learn and master Malay language not only for examination purposes, but as a means of communication and unity of different social backgrounds in a class as well as enhancing the spirit of patriotism among younger generation (Zamri et al. 2013; James et al. 2006). Therefore, various appropriate methods and teaching aids are applied in Malay language $T \& L$ so that it is easy for non-Malay students to master the language.

\section{Problem Statement}

The development of cyber technology and access to the growing internet demands changes in teaching and learning. The field of education needs to be improved in order to form students with the 21st century character. The features of the 21st century students are ability to make connections, wisely asking question, confidently communicate, thirst for knowledge, risk taking, curious, generating ideas, flexible, not giving up, listening and making reflection, have critical skills, mastering literacy skills, courageously trying, capable of self-thinking, making initiative, capable of working with people, making changes as well as having high personal qualities (MoE 2015). The implementation of the Primary School Standard Curriculum (KSSR) from 2011 and the Secondary School Standard Curriculum (KSSM) from 2017 is an educational transformation in order to create a balanced human capital that is capable of meeting current and future challenges (Nor, 2012).

In line with this, the MoE has collaborated with Malaysian Innovation Agency (under the Prime Minister's Department) to implement i-THINK program by introducing i-THINK Thinking Map as a tool that can stimulate student's thinking and potentially increase the level of mastery of Malay language among students (Vishalache et al. 2014). However, the effectiveness of using this map on Malay language T\&L among non-Malay students is not yet ascertained whether i-THINK Thinking Map can increase their Malay language proficiency or not. In addition, the question of the level of knowledge and acceptance of BBS race pupils on the use of i-THINK Thinking Map in Malay language as the second language T\&L should be resolved whether it will support the study conducted by Jumaliah and Zamri (2014), Farihah and Zamri (2014) also Hidayu and Yahya (2014).

The problems of Malay language T\&L process towards non-Malay students were studied by some researchers including Jaafar (2010) on the problems of Malay language T\&L among Chinese students. The problems that also influence Malay language T\&L is the attitude, interest and motivation of non-Malay students as in Zamri and Mohamed Amin (2008). In addition, a study conducted by Abu and Yusof (2014) on the attitude of indigenous children between the ages of 8 and 10 in the city of Kuala Lumpur on the mastery of Malay language as the second language. 
In Sarawak, Jerie and Zamri (2011) also conducted a study on the attitude and motivation of Iban's students in learning Malay as a second language.

One of the problems considered old but still practiced is the chalk and talk teaching method which is not relevant to the 21st century learning style. The 21st century learning features include aspects of communication, critical thinking, collaboration and creativity. However, educators still practice teacher-centered and conventional methods of T\&L in teaching Malay language (MoE 2015). Conventional teaching methods show teachers is dominating the classes (Fauziah et al. 2005). Conventional methods that is comparable to the chalk and talk method are simply less successful in attracting students which rather need a more dynamic and creative method (MoE 2015). In line with the 21st century learning conceptual approach, teachers are only instrumental in providing learning stimuli while students study in groups or use learning aids including reading materials, audio, video, computers and the internet (Tan and Hajar 2015). Therefore, the use of i-THINK thinking map as a tool of 21st century thinking is suitable to be applied by teachers in order to change the teacher-centered teaching method to student-centered as well as to stimulate and enhance student's thinking (Zamri et al. 2016) especially students as the second language speaker of Malay language to inculcate high-level thinking skills in the classroom and thus help the students to be proficient in Malay language.

Negative impressions as well as low interest among non-Malay learners towards Malay language learning are also an issue that needs to be highlighted. Chew Fong Peng (2009) found that nonMalay students were not interested in learning Malay language because they had the notion that learning Malay language is more centralized on Malay people. When they have no interest in a subject, they also have no motivation to study that subject (Ahmad et al. 2005). On the other hand, if the interest exists especially in Malay language T\&L, students are able to do all the activities such as role play, script writing, acting, etc. According to Tan and Hajar (2015), students prefer a quick and easy way to get answers rather than being asked to think deeper. They do not want to think and have no motivation to think.

In the process of mastering Malay as the second language, an effective teaching aid tools should be used in the language T\&L session because the process is challenging. Moreover, according to Hall (1996), learning something through the second language takes a long time (five to seven years) and becomes a major obstacle for students to gain knowledge. Vishalache et al. (2014) found that 90 percent of the information that came to our brain is in visual form. I-THINK thinking map as a graphical visual tool is seen as capable of stimulating interest, enhancing understanding and to assist in enhancing the achievement of second-language students towards mastery of Malay language. According Hyerle (1996), creator of i-THINK concludes that i-THINK thinking map as a visual language for thought. Thus, the use of i-THINK Thinking Map as a teaching aid is expected to help BBS students in mastering Malay language.

Research on the use of i-THINK Thinking Map in Malay language T\&L was studied by Jumaliah and Zamri (2014), Farihah and Zamri (2014), also Hidayu and Yahya (2014). Problems related to the T\&L process of Malay as the second language have been studied by Jaafar (2010), Jerie and Zamri 
Vol. 8, No. 4, 2019, E-ISSN: 2226-6348 @ 2019 HRMARS

(2011) also Zamri et al. (2013). However, there has been no study linking the use of i-THINK Map with the level of mastery of Malay language as the second language which refers to the T\&L towards students studying Malay as the second language. Therefore, this study examines whether the use of i-THINK Thinking Map helps the mastery of Malay language among BBS students.

\section{Research Purposes}

The purpose of this study is to identify the use of i-THINK Thinking Map on the mastery of Malay as the second language among Form Four students of Bidayuh Bukar Sadung ethnic in Serian District, Sarawak, Malaysia.

\section{Research Objectives}

This study is aimed at achieving five determined objectives in line with the hypothesis of the study.

1. Identifying the level of knowledge about the eight types of i-THINK Thinking Maps among BBS students.

2. Identifying the level of knowledge, acceptance and mastery of Malay language among BBS students towards the use of i-THINK Thinking Map in Malay language as the second language T\&L.

3. Identifying the frequency of i-THINK Thinking Maps usage in Malay as the second language T\&L based on gender.

4. Identifying whether there is a significant relationship between the use of i-THINK Thinking Map and the mastery of Malay language as the second language among BBS students.

5. Identify whether there is a significant correlation between the acceptance of i-THINK Thinking Map and the level of mastery of Malay language as the second language among BBS students.

\section{Methodology \\ Research Design}

The study is in the form of survey design. Survey study is a method of collecting information by asking lists of a set of questions to a selected individual sample from a studied population (Sabitha 2005). The questionnaire provided by researchers is about knowledge of BBS pupils on the use of i-Think Thinking Map, the acceptance of BBS pupils on the use of i-THINK in Malay language T\&L, and the mastery of Malay language among BBS pupils with the help of $\mathrm{i}$-THINK Thinking Map. The questionnaire was distributed to BBS students in four secondary schools in Serian District. Therefore, this method is appropriate to know, identify and strengthen quantitative data for research on the use of i-THINK Thinking Map of Malay Language as the second language among BBS students.

\section{Population, Location and Sample}

The population in this study is 557 Form Four students of Bidayuh Bukar Sadung (BBS) ethnic at Serian Division. The study involved only four of six government secondary schools in Serian District. The researcher chose the sample size determination by Krejcie and Morgan (1970). 
Vol. 8, No. 4, 2019, E-ISSN: 2226-6348 ㄷ 2019 HRMARS

Although 400 questionnaires were circulated, researchers are able to retrieve only 234 forms and this number is suitable based on Krejcie and Morgan (1970). Therefore, only 234 respondents are involved in this study.

\section{Research Instruments}

In this study, the instrument used to collect data is a questionnaire which contains statements to answer the research question. The same questionnaire is also used to collect data for pilot studies. The research instrument is modified from Jumaliah and Zamri (2014), Nik Nur Farihah and Zamri (2014), also Noor Hidayu and Yahya (2014). The set of questionnaire used in this study is divided into five parts, namely Part A, Part B, Part C, Part D and Part E. Part A is the basic information of respondents' backgrounds such as gender, class stream, parents' education level, parents' occupation, household income per month, spoken language, Malay language mastery level of family and frequency of i-THINK Map usage. Part B contains information about the level of knowledge of the respondents on the name and thinking process of the eight types of i-THINK Thinking Map. The questionnaire items in Part C, D and E use the 5-points Likert scale which contains five choices of answers from 1 to 5 . The scale rating is as follows: 1 . Strongly disagree (SD); 2. Disagree (D); 3. Less Disagree (LD; 4. Agree (S); and 5. Strongly Agree (SA). Respondents are required to choose the appropriate number based on the given statement.

Part $\mathrm{C}$ contains information regarding the respondents' level of knowledge on i-THINK Thinking Map usage in Malay language T\&L. Next, Section D contains information regarding the respondents' level of acceptance of i-THINK Thinking Map use in Malay language T\&L. Finally, Part E highlights the level of Malay language proficiency with the use of i-THINK Thinking Map in Malay language T\&L.

\section{Pilot Study}

This pilot study was conducted on 30 Form 4 pupils who are from BBS ethnic from a secondary school in Serian District in accordance with the characteristics of pupils who will be used to obtain the study data. The alpha Cronbach value for knowledge construct is 0.82 , the acceptance construct is 0.91 , and the mastery of Malay language construct is 0.88 .

\section{Data Analysis}

In this study, the data obtained are analyzed using the Statistical Package for Social Scientist (SPSS) version 22.0. Descriptive and inferential statistical methods are used for data presentation in this study.

\section{Research Findings \\ Respondent Demographics}

The findings in Table 1 show that the number of male and female respondents is 117 (50.0\%). The frequency distribution and percentage of respondents based on the class stream are 75 students (32.1\%) from science stream and 159 (67.9\%) are art stream students. For the frequency and percentage distribution of respondents based on parents' education, the findings showed that the majority of respondents' parents received secondary school education which are 146 
Vol. 8, No. 4, 2019, E-ISSN: 2226-6348 @ 2019 HRMARS

students (62.4\%), followed by primary school education (41 students (17.5\%), then college that is 25 students (10.7\%) and no education which are 22 students (9.4\%). In addition, 149 of respondent's parents worked as farmers which recorded the highest percentage of 64\%, while parents who are working as civil servants or in private company occupy the second highest number of students which are 52 (22\%), followed by other occupations which is 30 people (13\%) and the lowest is parents of respondents who work in business which are $3(1 \%)$.

Frequency and percentage distribution of respondents based on the type of parents' occupation showed that the majority of respondents' parents earned between RM500 to RM 1000 which are 88 students (37.6\%). The second highest number is parents who earn less than RM 500 that are 66 students (28.2\%). Next is the parents of the respondents earning between RM 1000 - RM 3000 are 58 students (24.8\%) and the least number of parents earn more than RM 3000, which are 22 (9.4\%). The finding showed that the Bidayuh Bukar Sadung (BBS) language is the most spoken language by the respondents and their family members that are 203 students (86.8\%). The second most spoken language by the respondents is Malay language which is about 26 students $(10.7 \%)$, while the least spoken language between respondents and their family members is English language which are 6 students (2.6\%).

Table 1: Profile of survey respondents

\begin{tabular}{llll}
\hline Profile & Groups & Frequency & Percentage (\%) \\
\hline Gender & Male & 117 & 50 \\
Class Stream & Female & 117 & 50 \\
\multirow{3}{*}{ Parents' education level } & Science & 75 & 32 \\
& No Education & 159 & 68 \\
& Primary School & 22 & 9 \\
& Secondary School & 41 & 18 \\
Parents' Occupation & University/College & 146 & 62 \\
& Public / private employees & 25 & 11 \\
& Farmer & 52 & 22 \\
Household income & Businessman & 3 & 64 \\
& Others & 30 & 1 \\
& Less than RM500 & 68 & 13 \\
& RM500-RM1000 & 88 & 28 \\
Spoken language in family & RM1000-RM2000 & 58 & 25 \\
& More than RM3000 & 22 & 9 \\
& Bidayuh Bukar Sadung & 203 & 87 \\
& Language & & \\
& Malay Language & 25 & 11 \\
Mastery of Malay & English & 6 & 3 \\
language among family & Not proficient & 4 & 2 \\
members & Less Proficient & 51 & 22 \\
& Proficient & 179 & 77 \\
\hline
\end{tabular}


Vol. 8, No. 4, 2019, E-ISSN: 2226-6348 @ 2019 HRMARS

\section{Students' Level of Knowledge about Eight Types of I-THINK Thinking Map}

Table 2 shows that 216 (92.3\%) respondents know the name of Tree Map which recorded the highest number for the name of i-THINK Thinking Map. On the other hand, the results of the survey found that 75 people (32.1\%) did not know the name of Multi-Flow Map. Most students aware of the thinking process for Flow Map that is 116 students (49.6\%). However, instead, a total of 127 students (54.0\%) did not know the thinking process involving Tree Map. As a whole, the level of knowledge of BBS students on eight types of i-THINK Thinking Maps is at the low level.

Table 2: Knowledge level of the eight types of i-THINK Thinking Maps

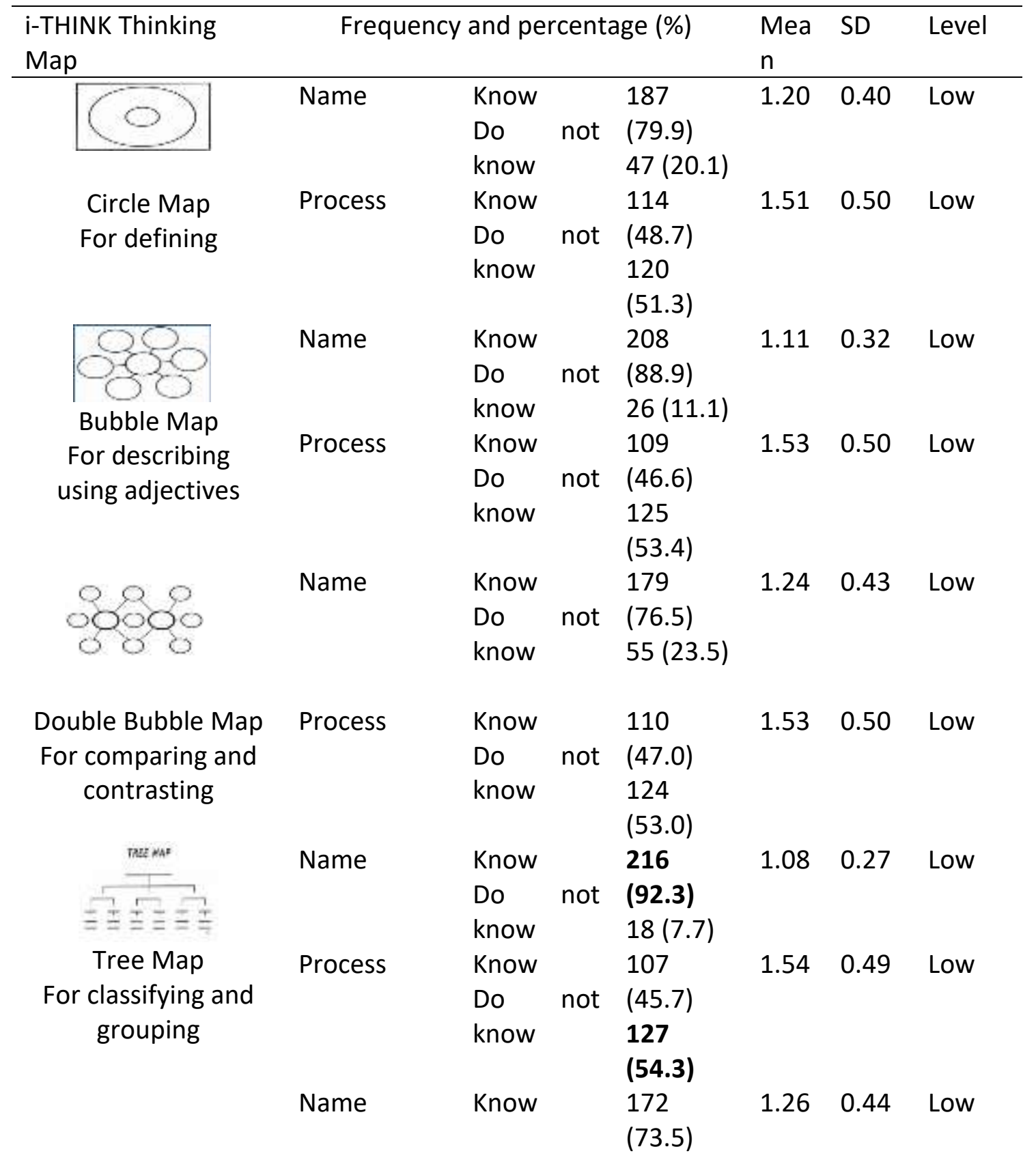


Vol. 8, No. 4, 2019, E-ISSN: 2226-6348 @ 2019 HRMARS

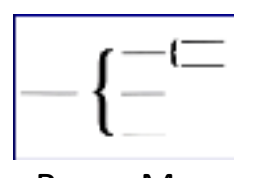

Brace Map

For analyzing whole

or parts

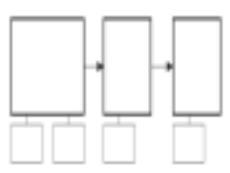

Flow Map

For sequencing and ordering

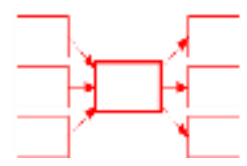

Multi Flow Map

For causes and effects

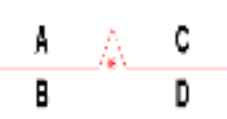

Bridge Map

For seeing analogies
Process

(2)

Name

Process

Process

k

Name

Process

Process

Name

Process

$\begin{array}{lll}\text { Do } & \text { not } & 62(26.5) \\ \text { know } & & \\ \text { Know } & 113\end{array}$

Do not (48.3)

know $\quad 121$

1.520 .50 Low

$\begin{array}{lrllll}\text { Know } & & 180 & 1.23 & 0.42 & \text { Low } \\ \text { Do } & \text { not } & (76.5) & & 2 & \\ \text { know } & & 54(23.1) & & & \\ \text { Know } & & \mathbf{1 1 6} & 1.50 & 0.50 & \text { Low } \\ \text { Do } & \text { not } & (\mathbf{4 9 . 6 )} & & 1 & \\ \text { know } & & 118 & & & \end{array}$

(50.4)

$\begin{array}{lrllll}\text { Know } & & 159 & 1.32 & 0.46 & \text { Low } \\ \text { Do } & \text { not } & (67.9) & & 8 & \\ \text { know } & & 75(32.1) & & & \\ \text { Know } & & 114 & 1.51 & 0.50 & \text { Low } \\ \text { Do } & \text { not } & (48.7) & & 1 & \\ \text { know } & & 120 & & & \end{array}$

$\begin{array}{lrllll}\text { Know } & & 183 & 1.22 & 0.41 & \text { Low } \\ \text { Do } & \text { not } & (78.2) & & 4 & \\ \text { know } & & 51(21.8) & & & \\ \text { Know } & & 109 & 1.53 & 0.50 & \text { Low } \\ \text { Do } & \text { not } & (46.6) & & 0 & \\ \text { know } & & 125 & & & \end{array}$

\section{Level of Knowledge on I-THINK Thinking Map Use in Malay Language T\&L}

In Table 3, knowledge item which is at a high level is item 5, that is 'I know that i-THINK Thinking Map makes me think easily' which obtained the highest mean (mean $=4.03$ ). Other knowledge items which are at the high level are item 7, 'I can use i-THINK Thinking Map well in Malay language T\&L' (mean = 3.74) and item 8, 'I find i-THINK Thinking Map is suitable for Malay Language learning activities' (mean = 3.97). Items with the lowest mean score are item 4 'I can recognize all eight i-THINK Thinking Maps' (mean = 3.20). As a whole, the total average mean score is 3.57, which is at a moderate level. This shows that the level of knowledge of BBS students towards i-THINK Thinking Map is still satisfactory. 
INTERNATIONAL JOURNAL OF ACADEMIC RESEARCH IN PROGRESSIVE EDUCATION AND DEVELOPMENT

Vol. 8, No. 4, 2019, E-ISSN: 2226-6348 @ 2019 HRMARS

Table 3: Mean and standard deviation analysis of students' knowledge on the use of I-THINK Thinking Map

\begin{tabular}{|c|c|c|c|c|c|c|c|c|c|}
\hline \multirow[t]{2}{*}{ No } & \multirow[t]{2}{*}{ Question Items } & \multicolumn{5}{|c|}{ Frequency and Percentage (\%) } & \multirow{2}{*}{$\begin{array}{l}\text { Mea } \\
n\end{array}$} & \multirow[t]{2}{*}{ SD } & \multirow[t]{2}{*}{ Level } \\
\hline & & SD & D & LD & A & SA & & & \\
\hline 1 & $\begin{array}{l}\text { I know about I- } \\
\text { THINK Thinking Map }\end{array}$ & $\begin{array}{c}3 \\
(1.3)\end{array}$ & $\begin{array}{c}24 \\
(10.3 \\
)\end{array}$ & $\begin{array}{c}96 \\
(41.0)\end{array}$ & $\begin{array}{c}98 \\
(41 . \\
9)\end{array}$ & $\begin{array}{c}13 \\
(5.6)\end{array}$ & 3.40 & 0.798 & Medium \\
\hline 2 & $\begin{array}{l}\text { I have knowledge } \\
\text { about how to use i- } \\
\text { THINK Thinking Map }\end{array}$ & $\begin{array}{c}6 \\
(2.6)\end{array}$ & $\begin{array}{c}23 \\
(9.8)\end{array}$ & $\begin{array}{c}113 \\
(48.3)\end{array}$ & $\begin{array}{c}83 \\
(35 . \\
5)\end{array}$ & $\begin{array}{c}9 \\
(3.8)\end{array}$ & 3.28 & 0.795 & Medium \\
\hline 3 & $\begin{array}{l}\text { I know the factors } \\
\text { that the Thinking } \\
\text { Maps are } \\
\text { introduced in the i- } \\
\text { THINK Program }\end{array}$ & $\begin{array}{c}4 \\
(1.7)\end{array}$ & $\begin{array}{c}31 \\
(13.2 \\
)\end{array}$ & $\begin{array}{c}109 \\
(46.6)\end{array}$ & $\begin{array}{c}77 \\
(32 . \\
9)\end{array}$ & $\begin{array}{c}13 \\
(5.6)\end{array}$ & 3.27 & 0.825 & Medium \\
\hline 4 & $\begin{array}{l}\text { I am able to } \\
\text { recognize all eight i- } \\
\text { THINK Thinking } \\
\text { Maps. }\end{array}$ & $\begin{array}{c}11 \\
(4.7)\end{array}$ & $\begin{array}{c}31 \\
(13.2 \\
)\end{array}$ & $\begin{array}{c}108 \\
(46.2)\end{array}$ & $\begin{array}{c}68 \\
(29 . \\
1)\end{array}$ & $\begin{array}{c}16 \\
(6.8)\end{array}$ & 3.20 & 0.921 & Medium \\
\hline 5 & $\begin{array}{l}\text { I know that i-THINK } \\
\text { Thinking Maps } \\
\text { makes it easy for } \\
\text { me to think. }\end{array}$ & $\begin{array}{c}3 \\
(1.3)\end{array}$ & $\begin{array}{c}6 \\
(2.6)\end{array}$ & $\begin{array}{c}43 \\
(18.4)\end{array}$ & $\begin{array}{c}112 \\
(47 . \\
9)\end{array}$ & $\begin{array}{c}70 \\
(29.9 \\
)\end{array}$ & 4.03 & 0.839 & High \\
\hline 6 & $\begin{array}{l}\text { I find that exposures } \\
\text { on the use of i- } \\
\text { THINK Thinking Map } \\
\text { in school are } \\
\text { adequate. }\end{array}$ & $\begin{array}{c}5 \\
(2.1)\end{array}$ & $\begin{array}{c}12 \\
(5.1)\end{array}$ & $\begin{array}{c}84 \\
(35.9)\end{array}$ & $\begin{array}{c}92 \\
(39 . \\
3)\end{array}$ & $\begin{array}{c}41 \\
(17.5 \\
)\end{array}$ & 3.65 & 0.901 & Medium \\
\hline 7 & $\begin{array}{l}\text { I can use i-THINK } \\
\text { Thinking Maps well } \\
\text { in Malay language } \\
\text { T\&L. }\end{array}$ & $\begin{array}{c}3 \\
(1.3)\end{array}$ & $\begin{array}{c}11 \\
(4.7)\end{array}$ & $\begin{array}{c}69 \\
(29.5)\end{array}$ & $\begin{array}{l}112 \\
(47 . \\
9)\end{array}$ & $\begin{array}{c}39 \\
(16.7 \\
)\end{array}$ & 3.74 & 0.837 & High \\
\hline 8 & $\begin{array}{l}\text { I find that i-THINK } \\
\text { Thinking Map is } \\
\text { suitable for Malay } \\
\text { language learning } \\
\text { activities. }\end{array}$ & $\begin{array}{c}4 \\
(1.7)\end{array}$ & $\begin{array}{c}8 \\
(3.4)\end{array}$ & $\begin{array}{c}44 \\
(18.8)\end{array}$ & $\begin{array}{l}114 \\
(48 . \\
7)\end{array}$ & $\begin{array}{c}64 \\
(27.4 \\
)\end{array}$ & 3.97 & 0.868 & High \\
\hline & $\begin{array}{c}\text { Average Mean } \\
\text { Score }\end{array}$ & & & & & & 3.57 & & Medium \\
\hline
\end{tabular}

Student' Level of Acceptance towards i-THINK Thinking Map Use in Malay Language T\&L Table 4 shows item 2 that is 'i-THINK Thinking Map is very useful in Malay language learning process' which obtained the highest mean value that is (mean = 3.96). Next followed by item 6 ' $i$ THINK Thinking Map usage makes it easier for me to remember a fact in Malay language T\& $L^{\prime}$ 


\section{INTERNATIONAL JOURNAL OF ACADEMIC RESEARCH IN PROGRESSIVE EDUCATION AND}

DEVELOPMENT

Vol. 8, No. 4, 2019, E-ISSN: 2226-6348 @ 2019 HRMARS

with value (mean $=3.94)$. The lowest mean value of the students' acceptance construct on the use of i-THINK Thinking Map is item 12 'l am sure the skill of constructing i-THINK Thinking Map requires a deep understanding and takes a long time to master' with the value (mean $=3.65)$. The average mean score obtained is 3.82 which are at a high level. This shows that the acceptance level of BBS students towards the use of i-THINK Thinking Map in Malay Language as the second language $T \& L$ is high.

Table 4: Mean and standard deviation analysis of students' acceptance levels on i-THINK Thinking Map use

\begin{tabular}{|c|c|c|c|c|c|c|c|c|c|}
\hline \multirow[t]{2}{*}{ No } & \multirow[t]{2}{*}{ Question Items } & \multicolumn{5}{|c|}{ Frequency and Percentage (\%) } & \multirow[t]{2}{*}{ Mean } & \multirow[t]{2}{*}{ SD } & \multirow[t]{2}{*}{ Level } \\
\hline & & SD & D & LD & A & SA & & & \\
\hline 1 & $\begin{array}{l}\text { Teaching using i-THINK } \\
\text { Thinking Maps makes me } \\
\text { want to learn Malay } \\
\text { language. }\end{array}$ & $\begin{array}{c}1 \\
(4)\end{array}$ & $\begin{array}{c}13 \\
(5.6 \\
)\end{array}$ & $\begin{array}{c}59 \\
(25.2)\end{array}$ & $\begin{array}{c}116 \\
(49 . \\
6)\end{array}$ & $\begin{array}{c}45 \\
(19 . \\
2)\end{array}$ & 3.82 & $\begin{array}{c}0.82 \\
1\end{array}$ & High \\
\hline 2 & $\begin{array}{l}\text { i-THINK Thinking Map is } \\
\text { useful in the process of } \\
\text { learning Malay language. }\end{array}$ & $\begin{array}{c}3 \\
(1.3)\end{array}$ & $\begin{array}{c}5 \\
(2.1 \\
)\end{array}$ & $\begin{array}{c}46 \\
(19.7)\end{array}$ & $\begin{array}{l}124 \\
(53 . \\
0)\end{array}$ & $\begin{array}{c}56 \\
(23 . \\
9)\end{array}$ & 3.96 & $\begin{array}{c}0.79 \\
9\end{array}$ & High \\
\hline 3 & $\begin{array}{l}\text { I like to learn Malay } \\
\text { language using i-THINK } \\
\text { Thinking Map. }\end{array}$ & $\begin{array}{c}7 \\
(3.0)\end{array}$ & $\begin{array}{c}7 \\
(3.0 \\
)\end{array}$ & $\begin{array}{c}66 \\
(28.2)\end{array}$ & $\begin{array}{l}119 \\
(50 . \\
9)\end{array}$ & $\begin{array}{c}42 \\
(17 . \\
9)\end{array}$ & 3.84 & $\begin{array}{c}0.74 \\
6\end{array}$ & High \\
\hline 4 & $\begin{array}{l}\text { I like to make notes and } \\
\text { exercises using i-THINK } \\
\text { Thinking Map in Malay } \\
\text { language T\&L. }\end{array}$ & $\begin{array}{c}1 \\
(0.4)\end{array}$ & $\begin{array}{c}12 \\
(5.1 \\
)\end{array}$ & $\begin{array}{c}66 \\
(28.2)\end{array}$ & $\begin{array}{c}106 \\
(45 . \\
3)\end{array}$ & $\begin{array}{c}49 \\
(20 . \\
9)\end{array}$ & 3.81 & $\begin{array}{c}0.83 \\
8\end{array}$ & High \\
\hline 5 & $\begin{array}{l}\text { Lesson using i-THINK } \\
\text { Thinking Map is very } \\
\text { effective to help me better } \\
\text { understand something in } \\
\text { Malay language T\&L. }\end{array}$ & $\begin{array}{c}3 \\
(1.3)\end{array}$ & $\begin{array}{c}5 \\
(2.1 \\
)\end{array}$ & $\begin{array}{c}59 \\
(25.2)\end{array}$ & $\begin{array}{l}118 \\
(50 . \\
4)\end{array}$ & $\begin{array}{c}49 \\
(20 . \\
9)\end{array}$ & 3.88 & $\begin{array}{c}0.80 \\
6\end{array}$ & High \\
\hline 6 & $\begin{array}{l}\text { The use of i-THINK Thinking } \\
\text { Maps makes it easier to } \\
\text { remember a fact in Malay } \\
\text { language T\&L. }\end{array}$ & $\begin{array}{c}2 \\
(0.9)\end{array}$ & $\begin{array}{c}7 \\
(3.0 \\
1\end{array}$ & $\begin{array}{c}47 \\
(20.1)\end{array}$ & $\begin{array}{c}125 \\
(53 . \\
4)\end{array}$ & $\begin{array}{c}53 \\
(22 \\
6)\end{array}$ & 3.94 & $\begin{array}{c}0.78 \\
9\end{array}$ & High \\
\hline 7 & $\begin{array}{l}\text { I-THINK Thinking Maps } \\
\text { further help me to form } \\
\text { the whole topical content } \\
\text { of Malay language T\&L. }\end{array}$ & $\begin{array}{c}2 \\
(0.9)\end{array}$ & $\begin{array}{c}9 \\
(3.8 \\
1\end{array}$ & $\begin{array}{c}54 \\
(23.1)\end{array}$ & $\begin{array}{c}127 \\
(54 . \\
3)\end{array}$ & $\begin{array}{r}42 \\
(17 . \\
9)\end{array}$ & 3.85 & $\begin{array}{c}0.78 \\
7\end{array}$ & High \\
\hline 8 & $\begin{array}{l}\text { Learning assisted by i- } \\
\text { THINK Thinking Maps is } \\
\text { fun, easy and realistic. }\end{array}$ & $\begin{array}{c}1 \\
(0.4)\end{array}$ & $\begin{array}{c}6 \\
(2.6 \\
)\end{array}$ & $\begin{array}{c}55 \\
(23.5)\end{array}$ & $\begin{array}{l}122 \\
(52 . \\
1)\end{array}$ & $\begin{array}{c}50 \\
(21 . \\
4)\end{array}$ & 3.91 & $\begin{array}{c}0.76 \\
5\end{array}$ & High \\
\hline
\end{tabular}


INTERNATIONAL JOURNAL OF ACADEMIC RESEARCH IN PROGRESSIVE EDUCATION AND

DEVELOPMENT

Vol. 8, No. 4, 2019, E-ISSN: 2226-6348 @ 2019 HRMARS

9 Using i-THINK Thinking Map, I can illustrate the relevance of an important

$\begin{array}{cc}2 & 9 \\ (0.9) & (3.8 \\ & 1\end{array}$
55

$144 \quad 24$

concept in a topic in Malay language T\&L.

10 I can understand more specific or more general concepts using i-THINK

$\begin{array}{cccccccc}2 & 10 & 79 & 122 & 21 & 3.64 & 0.74 & \text { Medium } \\ (0.9) & (4.3 & (33.8) & (52 . & (9.0) & & 1 & \\ & ) & & 1) & & & & \\ & & & & & & & \\ & & & & & & & \\ - & 9 & 61 & 130 & 34 & 3.81 & 0.72 & \text { High } \\ & (3.8 & (26.1) & (55 . & (14 . & & 5 & \\ & 1 & & 6) & 5) & & & \\ & 16 & 61 & 127 & 25 & 3.65 & 0.84 & \text { Medium } \\ 5 & 16.8 & (26.1) & (54 . & (10 . & & 3 & \\ (2.1) & (6.8 & & 3) & 7) & & & \\ & 1 & & & & & & \end{array}$
Thinking Map in Malay language T\&L.

11 I-THINK Thinking Map can help me to link one topic to another in a topic in Malay language T\&L.

12 I am sure that the skills to build i-THINK Thinking

Maps require a deep understanding and takes a long time to master

\section{Level of Students' Malay Language Mastery using i-THINK Thinking Map}

The findings showed that item 6; 'i-THINK Thinking Map helps me understand the lessons taught by Malay Language teachers' to get the highest mean value of 3.93. It is followed by item 5 ' $i$ THINK Thinking Map helps me understand the meaning of a sentence written in Malay' (mean = 3.83). The lowest mean value refers to item 2; 'I can write in Malay without making spelling mistakes in Malay language T\&L which used i-THINK Thinking Map' with (mean = 3.63). The average mean score obtained is 3.75 which are at a high level. This means that the level of mastery of Malay language among BBS students increased when i-THINK Thinking Map is used in learning Malay as the second language.

Table 5: Students' level of Malay language mastery through i-THINK Thinking Map usage in learning Malay language

\begin{tabular}{|c|c|c|c|c|c|c|c|c|c|}
\hline \multirow[t]{2}{*}{ No } & \multirow[t]{2}{*}{ Item } & \multicolumn{5}{|c|}{ Frequency and Percentage (\%) } & \multirow{2}{*}{$\begin{array}{c}\text { Mea } \\
n\end{array}$} & \multirow[t]{2}{*}{ SD } & \multirow[t]{2}{*}{ Level } \\
\hline & & SD & D & LD & A & SA & & & \\
\hline \multirow[t]{3}{*}{1} & I-THINK Thinking Maps help me & 1 & 7 & 64 & 130 & 32 & 3.79 & 0.726 & High \\
\hline & build Malay sentences correctly & $(0.4$ & (3.0 & $(27.4$ & $(55.6$ & $(13.7$ & & & \\
\hline & using the words I learned recently. & 1 & ) & ) & ) & ) & & & \\
\hline \multirow[t]{3}{*}{2} & I can write in Malay without making & - & 7 & 96 & 108 & 23 & 3.63 & 0.701 & Medium \\
\hline & spelling mistakes in Malay language & & (3.0 & $(41.0$ & $(46.2$ & (9.8) & & & \\
\hline & $\begin{array}{l}\text { T\&L which used i-THINK Thinking } \\
\text { Map. }\end{array}$ & & ) & ) & ) & & & & \\
\hline
\end{tabular}


INTERNATIONAL JOURNAL OF ACADEMIC RESEARCH IN PROGRESSIVE EDUCATION AND DEVELOPMENT

Vol. 8, No. 4, 2019, E-ISSN: 2226-6348 @ 2019 HRMARS

3

I am able to produce good Malay essay when i-THINK Thinking Map is used in the lesson.

4 I managed to complete Malay language assignments correctly with the help of i-THINK Thinking Map.

$5 \quad$ I-THINK Thinking Maps help me understand the meaning of a sentence written in Malay language.

6 I-THINK Thinking Maps help me understand the lessons taught by Malay Language teachers.

7 I am able to talk with Malay language teachers by using proper and correct Malay language as a result of i-THINK Thinking Map use in Malay language T\&L.

8 I understand the instructions or questions in Malay language either verbally or in writing using i-THINK Thinking Map.

$9 \quad$ I-THINK Thinking Map makes me understand the reading material written in Malay language.

10 Learning using i-THINK Thinking Maps helps me speak Malay language with the correct vocabulary.

11 I use Malay language properly and correctly when I do group discussion as a result of using iTHINK Thinking Maps.

12 Learning using i-THINK Thinking Maps allows me to present the result of a group discussion using proper and correct Malay language

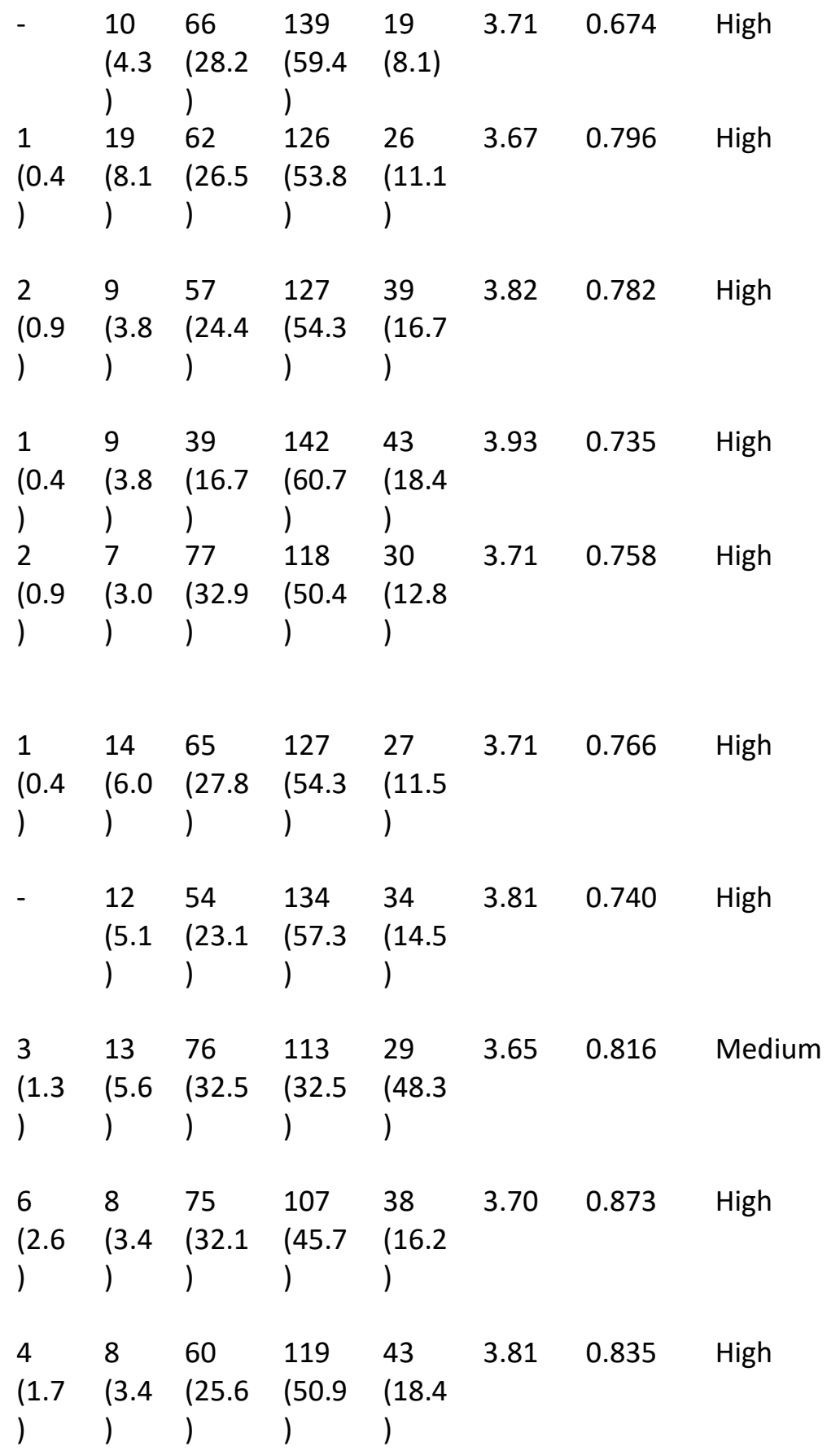

Frequency of I-THINK Thinking Maps Usage in Malay language T\&L Based on Gender

Ho1: $\quad$ There is no difference in frequency of i-THINK Thinking Map usage in Malay language as the second language $T \& L$ between genders. 
Vol. 8, No. 4, 2019, E-ISSN: 2226-6348 @ 2019 HRMARS

The analysis showed that the results of Chi Squared Test $\left(x^{2}=0.08, d f=2, p>0.05\right)$ showed that there is no significant difference between the use of $\mathrm{i}$-THINK Thinking Map between genders among BBS students. Significant value is at $p=0.96$. Therefore, Ho1 is accepted.

Table 6: Chi Square Test of difference in frequency of i-THINK Thinking Map usage between genders

\begin{tabular}{|c|c|c|c|c|c|c|c|}
\hline & & \multicolumn{3}{|c|}{$\begin{array}{c}\text { Frequency of i-THINK Thinking } \\
\text { Maps usage } \\
\text { (Frequency and Percentage) }\end{array}$} & \multirow[b]{2}{*}{$x^{2}$} & \multirow[b]{2}{*}{ df } & \multirow[b]{2}{*}{ Sig. (p) } \\
\hline & & Always & Seldom & $\begin{array}{l}\text { Neve } \\
r\end{array}$ & & & \\
\hline \multirow[t]{2}{*}{ Gender } & Male & $\begin{array}{l}12 \\
(10.3)\end{array}$ & $98(83.8)$ & $\begin{array}{l}7 \\
(6.0)\end{array}$ & 0.08 & 2 & 0.96 \\
\hline & Female & $\begin{array}{l}12 \\
(10.3)\end{array}$ & 99 (84.6) & $\begin{array}{l}6 \\
(5.1)\end{array}$ & & & \\
\hline
\end{tabular}

\section{Correlation between Knowledge about i-THINK Thinking Maps and Malay Language Proficiency}

Ho2: There is no significant relationship between the use of i-THINK Thinking Map and the proficiency level of Malay language as the second language among BBS students

The results of the analysis showed that the knowledge about i-THINK Thinking Map and the mastery of Malay language had a significant moderate relationship $(r=0.586, p<0.001)$ as shown in Table 7. Therefore, $\mathrm{Ho} 2$ is rejected. This shows that the knowledge about i-THINK Thinking Map usage can help the mastery of Malay language among BBS students.

Table 7: Spearman's Rho Correlation between knowledge about i-THINK Map and Malay Language mastery

\begin{tabular}{llccr}
\hline \multicolumn{2}{c}{ Relationship } & $\begin{array}{l}\text { Spearman's rho } \\
\text { Correlation }(\boldsymbol{r})\end{array}$ & Sig. & Interpretation \\
\hline $\begin{array}{l}\text { Knowledge about i- } \\
\text { THINK Thinking }\end{array}$ & Malay language & .586 & .000 & Moderate \\
Map & Proficiency & & & \\
\hline
\end{tabular}

Significant level at 0.05

Relationship between Acceptance of i-THINK Thinking Map Usage in Malay Language as the Second Language T\&L and Mastery of Malay Language

Ho3: There is no significant relationship between i-THINK Thinking Map acceptance and the level of mastery of Malay language as the second language among BBS students

Based on Table 8, the findings show that the acceptance of using i-THINK Thinking Maps has a significant positive correlation with Malay language mastery of BBS students. The strength of this relationship is strong. This can be seen in the value of $r=0.718$ at significant level $p<0.001$. 
Vol. 8, No. 4, 2019, E-ISSN: 2226-6348 @ 2019 HRMARS

Therefore, Ho3 is rejected. This showed that the high acceptance of i-THINK Thinking Map usage can help the mastery of Malay language among BBS students.

Table 8: Spearman's Rho test between the acceptance of i-THINK Thinking Map in Malay T\&L and the mastery of Malay language

\begin{tabular}{lcccc}
\hline \multicolumn{2}{c}{ Relationship } & $\begin{array}{l}\text { Spearman's rho } \\
\text { Correlation }(r)\end{array}$ & Sig. & Interpretation \\
\hline i-THINK Thinking & $\begin{array}{l}\text { Malay language } \\
\text { Map Acceptance }\end{array}$ & .718 & .000 & Strong \\
\hline
\end{tabular}

Significant level at 0.05

\section{Discussions}

\section{Student Knowledge Level on Eight Types of i-THINK Thinking Maps and Their Uses in} Malay Language T\&L

BBS students' knowledge about the eight types of i-THINK Thinking Map outlined by the Curriculum Development Division (BPK) is low. The Tree Map is most easily recognized by the BBS pupils, but most do not know the Multi Flow Map. The findings also found that BBS students are most familiar with the Flow Map thought process that is used to sequence a process (MoE 2012; Jumaliah 2014; Rahimah \& Zamri 2015). However, most students do not know the process of thinking involving Tree Map which is for classifying and grouping. Furthermore, the findings on the knowledge level of BBS students about i-THINK Thinking Maps usage in Malay language T\&L is still satisfactory as the average mean score obtained is 3.57 which are at a moderate level.

The findings of this study are contrary to the study conducted by Jumaliah and Zamri (2014) which shows that the level of students' knowledge about the name and function of each Thinking Map is high. The researcher found that the sample of the study conducted by Jumaliah and Zamri (2014) had an early exposure to i-THINK Thinking Map at the beginning of 2013 school session when they attended i-THINK Thinking Map expansion course as the school of the study sample was selected as the expansion school for i-THINK program. On the contrary, BBS pupils which are the sample of the study obtained knowledge on names and process of Thinking Maps only through their Malay Language teachers or from internet sources or reading materials related to i-THINK Thinking Map.

The use of Flow Map is also an option and had been used by students of Advanced Nutrition and Metabolism courses at the University of East Carolina in understanding and mastering the process of articles writing as studied by Callagher (2011). According to Callagher (2011), a structured Flow Map facilitates students to read and evaluate the process of producing good quality articles. The researcher assumed that the respondents successfully compared the effectiveness of teaching methods with or without the use of i-THINK Thinking Map in Malay language T\&L. i-THINK Thinking Maps is a thinking tool that stimulates students' thinking skills that make them able to solve problems and making decision 
Vol. 8, No. 4, 2019, E-ISSN: 2226-6348 @ 2019 HRMARS

\section{Students' Acceptance Level of i-THINK Thinking Map Usage}

The average mean score obtained is 3.82 which are at a high level. This shows that the level of acceptance of BBS students towards i-THINK Thinking Map usage in learning Malay as the second language is high. The findings of this study have similarities with the findings of Nik Nur Farihah (2014) regarding the level of acceptance of respondents on i-THINK Thinking Map usage. Nik Nur Farihah (2014) found that respondents agreed that i-THINK Thinking Map is useful in the process of learning Malay language which get the highest mean (mean $=4.58$ ) compared to the other three items asked in this category. She explained that the students' acceptance factor affects their attitude and readiness towards i-THINK Thinking Map use in Malay language T\&L. Tan and Siti Hajar (2015) explains that it is very important to test the acceptance of pupils on new methods of teaching. This is because if there is a high level of acceptance, it means that students have a deep interest to use that method in $T \& L$ of a subject.

The researcher believes that the use of $\mathrm{i}$-THINK Thinking Map in Malay Language as the second language $T \& L$ is able to solve the problems in Malay language $T \& L$ among non-Malay students, particularly among BBS students. This is because the level of acceptance among BBS students towards i-THINK Thinking Map use proves that student's awareness and confidence about the importance of i-THINK Thinking Maps use in learning Malay language.

\section{Level of Malay Language Proficiency through the Use of i-THINK Thinking Map in in Malay Language Learning as the Second Language among BBS students}

The findings of this study show that the average mean score obtained is 3.75 which are at high level. The findings of this study have similarities with the findings of the study conducted by Mohd Izzuddin and Zamri (2016) which shows that the mean score for grammar, reading skills, writing skills, listening and speaking skills and language art aspects after T\&L using i-THINK Thinking Map are at a high level among treatment group of primary school pupil in Pekan, Pahang. The findings in this study also showed that there are significant differences of $p<0.05$ in terms of Malay language achievement score of treatment group and control group after Malay language T\&L using i-THINK Thinking Map.

\section{I-THINK Thinking Maps Usage Frequency in Malay Language T\&L between Genders}

The findings show that there is no significant difference in the usage frequency of i-THINK Thinking Maps between genders among BBS pupils. Significant value is at the level of $p=0.96$. Therefore, Ho1 is accepted. The findings of this study are in line with the findings of Zuraidah (2008) regarding the skills, attitude and frequency of computer use among 121 Malay Language teachers from several secondary schools in Hulu Langat district as the respondents. The findings show that there is no significant difference in the frequency of computer usage among Malay language teachers between male and female teachers. The t-test performed showed $t$-values $(119)=-0.962$ and at significant levels $p=0.338>\alpha=0.05$.

\section{Relationship between Knowledge on i-THINK Thinking Map and Malay Language Mastery}

The findings of this study are to examine the relationship between the level of knowledge on $\mathrm{i}$ THINK Thinking Map and the level of Malay language mastery among BBS students. Based on the analysis, the findings show that there is a moderate relationship between knowledge on i-THINK 
Vol. 8, No. 4, 2019, E-ISSN: 2226-6348 @ 2019 HRMARS

Thinking Map and the mastery of Malay Language as the second language. The correlation coefficient value obtained is $r=0.586$. This means Malay language mastery of BBS students is still influenced by their knowledge about i-THINK Thinking Map. Clearly, students with the knowledge of i-THINK Thinking Map usage in learning Malay language have the ability to master the language easily because i-THIK Thinking Map is a thinking tool that stimulates their thinking skills.

The findings of this study are consistent with the findings of Lee (2003) which studied about the relationship between basic scientific knowledge and achievement of students in Chemistry subject amongst 100 form four pure science students of SMK Dato'Undang Musa Al-Haj and SMK Undang Jelebu in Kuala Klawang Jelebu, Negeri Sembilan. The results showed that there was a strong correlation between basic scientific knowledge and the achievement of students in Chemistry with the correlation coefficient obtained was $r=0.751$. This is because effective learning and understanding comes from the existing knowledge of a pupil.

\section{Relationship between Acceptance of i-THINK Thinking Map Usage in Malay language as the Second Language T\&L and Malay Language Mastery}

The findings show that the acceptance of i-THINK Thinking Map use in BBS pupils has significant positive correlation with the Malay language mastery of Bukar Sadung students. The strength of this relationship is at a strong level based on the value of $r=0.718$ and at the significant level $p<$ 0.001.

The findings of this study have similarities with the study conducted by Khairatul Akmar (2014) regarding the factors influencing the mastery of Arabic language skills among students of Bachelor of Arabic Language Program (PSMBA) at institutions of higher learning (IPTA) in Malaysia. The findings show that there is a significant correlation between the students' internal factors (attitudes, motivation, and perceptions) and the level of Arabic language proficiency for students' language skills namely listening, speaking, reading, and writing. The overall average of the relationship between the internal factors and the level of Arabic language proficiency in Arabic based on Pearson's correlation test is $r=0.392$ and at significant level $p>0.001$.

This implies that high acceptance of students towards i-THINK Thinking Map usage of in Malay language $T \& L$ can help improve the mastery of Malay language which involves language skills mastery (listening, speaking, reading and writing). Consequently, it can be concluded that the higher the students' acceptance of i-THINK Thinking Map usage in Malay language T\&L, the higher the level of Malay language mastery in terms of language proficiency.

\section{Research Implications and Suggestions}

The findings show that students' level of knowledge on the name and process of thinking of eight types of $\mathrm{i}$-THINK Thinking Maps is at a low level but knowledge on the use and acceptance of the map is high in Malay language as the second language T\&L. Pupils are encouraged to use i-THINK Map in learning Malay language as they are able to stimulate students' high thinking skills to further assist Malay language mastery even if it is the second language. 
Vol. 8, No. 4, 2019, E-ISSN: 2226-6348 @ 2019 HRMARS

The findings show that the use of i-THINK Thinking Maps in Malay language as the second language $T \& L$ is rarely applied. Researchers think teachers as tutor, facilitators and counselors in the classroom rarely use i-THINK Thinking Maps as a thinking tool to stimulate high-level thinking skills in the classroom. The implications of the study is to educate the teachers to apply the thinking map as a means of thinking to stimulate the memory and thinking skills of the students in order to help them master Malay language easily.

As a primary leader in school, administrators should take advantage of the programs introduced by the Education Ministry as an effort to create 21st century learning as well as to produce students who are able to think highly in learning. The administrator should ensure that Malay Language teachers attend courses on i-THINK Maps. In addition, they should ensure that i-THINK programs are implemented in schools, especially in Malay language teaching and learning process.

From this study, it helps the Malaysian Ministry of Education (MoE) through the Education Development Division to plan and carry out activities related to the implementation of i-THINK programs in schools. And the same time, the contribution of this study is to help the various parties, especially the schools where teachers can conduct their teaching and learning activities that engage students in engaging in fun sessions. Effective activities are activities that attract students, receive them, have fun, are able to stimulate thinking skills and thus facilitate mastery of the subject.

\section{Conclusion}

In conclusion, this study was conducted to identify the use of i-THINK Thinking Map in Malay language as the second language T\&L among form four BBS students at Serian District, Sarawak, Malaysia. Clearly, in the findings of the study, BBS students are aware of the importance of iTHINK Thinking Map as a tool that can stimulate high level thinking skills and thus help them to master language skills in Malay language subject although they are rarely used in Malay language T\&L. Educators should often use the maps in Malay language teaching so that the problems in the $T \& L$ can be overcome as well as in line with the 21 st century learning. Therefore, this study can help students to better understand and easy to learn the Malay language, the study can help teachers in teaching method use of i-THINK Thinking Map in Malay language.

\section{References}

Rahim, A., \& Sharifudin, M. Y. (2014). The Attitude of the Orang Asli Children in Kuala Lumpur to the mastery of Malay Language as the Second Language. Malay Language Education Journal, 4 (2): 57-66.

Rashid, A. J. (2010). The Problem in Teaching and Learning among Chinese Students. Jurnal Malaysian Education Dean's Council, 6, Disember.

Callagher. (2011). Using thinking maps to research writing in upper level undergraduate classes. Journal of Family \& Consumer Sciences Education, 29 (2).

Chew, F. P. (2016). The Problem of Learning Malay among Primary School Chinese Students. Malay Language Education Journal, 6 (2): 10-22. 
Fauziah, A., Parilah, M. S., \& Shamsuddeen, A. A. (2005). Choice of Teaching Methods: TeacherCentered or Student-Centered. Educational Research Journal, 7 (Dec): 57-74.

Hyerle, D. (1996). Thinking Maps: Seeing is Understanding. Educational Leadership, 53 (12): 8589.

James, Ahi, A. S., \& Nicholas, A. (2006). Creating a New Bidayuh Identity. (Eds). Kuching: Dayak Bidayuh National Association.

Jerie, P. L., \& Zamri, M. (2011). The Attitude and Motivation of Iban Students in Malay Language as a Second Language. Malay Language Education Journal, 1 (1): 13-25.

Jumaliah, M., \& Zamri, M. (2014). The use of i-Think Thinking Map in Secondary School Malay Learning Education. Proceedings Seminar of Postgraduate Seminar on Malay Language \& Third Malay Language Literature, 2014. Bangi: Faculty of Education Press, Universiti Kebangsaan Malaysia.

Jumaliah, M. (2014). Using of i-Think Thinking Map in Upper Secondary Malay Language Learning. Project Paper of Master Education. Faculty of Education, Universiti Kebangsaan Malaysia.

Akmar, K. A. L. (2014). Affecting factors of Arabic Language proficiency among Undergraduate Program Students at Malaysia Public Higher Learning Institution. Thesis of Doctor of Philosophy. Faculty of Education, Universiti Kebangsaan Malaysia.

Krejcie, R. V., \& Morgan, D. W. (1970). Determining Sample Size for Research Activities. Education and Psychological Measurement, 30: 607-610.

Lee, S. C. (2003). The relationship of attitude to chemistry and basic science knowledge with student achievement in Chemistry. Thesis of Master Education. Faculty of Education, Universiti Kebangsaan Malaysia.

Loganathan, R. (2014). i-Think in Malay Education Subject. In. Vishalache, B. et al. (2014). I-Think Application in Education. Kuala Lumpur: Dewan Bahasa and Pustaka Press.

Malaysia Ministry of Education. (2015). Shift Bulletin. No. 4/2015. Putrajaya: Curriculum Development Division.

Malaysian Ministry of Education Ministry. (2012). i-Think Program Embraces Thinking Skills. Putrajaya: Curriculum Development Division of Ministry of Education.

Malaysian Ministry of Education. (2000). KBSM Malay Language Form Four. Kuala Lumpur: Curriculum Development Center.

Izzuddin, M. C. A. \& Zamri, M. (2016). The Effectiveness of Using i-Think in Malay Language Teaching and Learning at Primary Schools. Proceedings of Postgraduate Malay Education \& Malay Language Literary Education. Bangi: Faculty of Education Press, Universiti Kebangsaan Malaysia.

Farihah, N. N. N. H. \& Zamri, M. (2014). The Effectiveness of the Methods of Thinking i-Think Map on Achievements, Attitudes and Readiness of Form Students 4. Proceedings of the Seminar of Postgraduate Seminar on Malay Language \& Third Malay Language Literature. Bangi: Faculty of Education Press, Universiti Kebangsaan Malaysia.

Farihah, N. N. N. H. (2014). The Effectiveness of the i-Think thinking map method on the Achievement, Attitude, Willingness and Acceptance of form four pupils. Project Paper of Master Education. Faculty of Education, Universiti Kebangsaan Malaysia.

Hidayu, N. M. R. \& Yahya, O. (2014). The Effectiveness of the Thinking Map (i-Think) in Writing Proficiency in Chinese-Type Schools. Proceeding of Postgraduate Seminar on Malay 
Vol. 8, No. 4, 2019, E-ISSN: 2226-6348 C 2019 HRMARS

Language \& Third Malay Language Literature. Bangi: Faculty of Education Press, Universiti Kebangsaan Malaysia.

Sabitha, M. (2005). Social Science Research Method. Selangor: Prentice Hall Pearson (M).

Nor, S. P. (2012). Malay Language Teachers' Concern in Implementing Critical Thinking Skills and Creative Skills. Malay Language Education Journal, 2 (1): 19-31.

Tan, S. Y., \& Hajar, S. H. (2015). Effective Teaching of Higher-Order Thinking in Education. The Online Journal of Distance Education and e-Learning, 3 (2): 41-47.

Zamri, M., \& Amin, M. E. (2008). The Attitude of Chinese Students towards Learning Malay as a Second Language. Zamri, M. (Eds.). Psycholinguistics in Teaching and Learning Malay Language, 264-284. Shah Alam: Karisma Publication.

Zamri, M., Jumaliah, M. \& Yahya, O. (2016). Students' Thinking and Ceativity Maps. Saemah, R. \& Zamri, M. (Eds.). Creativity in Teaching and Learning. Bangi: Universiti Kebangsaan Malaysia Press.

Zamri, M., Ayu, K. A. G. \& Ruzanna, W. M. (2016). The use of Malay language Learning. Malay Language Education Journal, 6 (1): 38-51.

Zamri, M., Izham, M. I., Razaq, A., \& Mahdum. (2013). The Attitude and Interest of non-Malay students when learning Malay as a second language. Zamri, M. et al. (Eds.). Regional Education Research Group. Bangi: Faculty of Education Press, Universiti Kebangsaan Malaysia.

Zuraidah, S. (2008). Skills, attitude and computer usage frequency amalan Malay Language teachers. Project Paper of Master Education. Faculty of Education, Universiti Kebangsaan Malaysia. 